\title{
Influence of Active Charcoal and Plant Position on Some Morphological Parameters of a Local Variety of Okra (Abelmoschus caillei)
}

\author{
Kouame N'Guessan*, Koffi Ahébé Marie Hélène, Kouassi N'Dri Jacob, \\ N'Guessan N'Guessan Alain, Yatty Kouadio Justin \\ Unit of Teaching of Plant Physiology and Biotechnology, UFR Agroforestry, UniversityJean Lorougnon GUEDE (UJLoG), \\ Daloa, Côte d'Ivoire \\ Email: ^maximekouamelma@yahoo.fr
}

How to cite this paper: N'Guessan, K., Hélène, K.A.M., Jacob, K.N., Alain, N.N. and Justin, Y.K. (2017) Influence of Active Charcoal and Plant Position on Some Morphological Parameters of a Local Variety of Okra (Abelmoschus caillei). American Journal of Plant Sciences, 8, 2021-2030.

https://doi.org/10.4236/ajps.2017.89135

Received: June 28, 2017

Accepted: July 30, 2017

Published: August 2, 2017

Copyright $\odot 2017$ by authors and Scientific Research Publishing Inc. This work is licensed under the Creative Commons Attribution International License (CC BY 4.0).

http://creativecommons.org/licenses/by/4.0/

cC) $\underset{\mathrm{EY}}{\text { (i) Open Access }}$

\begin{abstract}
Okra is a plant rich in nutrients and is very well consumed in Côte d'Ivoire. Despite its many benefits, the production of this vegetable is still weak in our country. The reasons for this include the inadequate selection of varieties, the high cost of inputs and the poverty of the soil for its cultivation. One of the alternatives for sustained production is to solve the problem of soil fertility. In the case of our work, the aim is to improve the yield of okra. To achieve this goal, experiments were undertaken to evaluate the impact of activated charcoal on morphological parameters of a local okra variety. For this purpose, the charcoal used was activated in three different times (activation time equal to 0 days, 15 days and 30 days). The experimental device used is a split-plot with three repetitions, each comprising 12 elementary plots. The various charcoals were buried the same day. Then, the seedling was done with two positions including outside position and inside position. Observations were made on 360 plants. An analysis of the variances was carried out on the morphological parameters. Fruit mass is the variable most influenced by activated charcoal. Thus, the greatest value of the mass was obtained with the charcoal CA0, with outside position.
\end{abstract}

\section{Keywords}

Activated Charcoal, Okra, Position, Morphological Parameters

\section{Introduction}

The agricultural sector formed the basis for Côte d'Ivoire economic development as soon as it became independent. In order to take advantage of this sector, the 
Ivorian government has focused on the development of industrial crops, notably the coffee-cocoa sector since the 1960. From the year 2000, it contributed to the development of the rubber, Cotton-cashew nut and oil palm [1].

However, the food crops that constitute the basis of the direct food supply to the Ivorians have all been kept out of public investment. They do not benefit from any particular management and organizational reform [1]. As a result, there is often low production or even discarding of certain crops, including okra. Indeed, okra is heavily consumed in two forms (fresh and dry) in Côte d'Ivoire due to $5.5 \mathrm{~kg}$ per capita [1]. At the nutritional level, okra is rich in carbohydrate ( $7 \%-8 \%$ dry matter) and protein (1.8\% dry matter); it also contains $0.056 \%$ phosphorus, $0.043 \%$ magnesium, $0.09 \%$ of calcium and its seeds are very rich in protein (20\%) and lipid (14\%). Its sanitary virtues are multiple: it is an antiinflammatory, a diuretic, an antiseptic and an antispasmodic. The okra is used in the composition of syrup used against colds and bronchial problems. Its stem is used for the manufacture of pulp and the making of cords [2]. Despite its social and economic importance, okra culture is still weak in our country. However, low okra production can result from several factors: lack of adequate inputs, lack of skilled labor, poor cropping practices and above all, soil fertility levels. The leaching of culture media leads to consequences such as soil acidification, increased fertilization costs, loss of moving parts and the threat of environmental health [3]. In order to compensate for this, alternatives must be put in place that can influence the evolution of agricultural soils. They must be able to contribute to the fixation of nutrients and make them available to plants. Activated charcoal appears, therefore a means to address this concern. Indeed, coal has large properties capable of improving the condition of agricultural soils. It contributes to the reduction of soil acidity [3], accelerates the activation of microorganisms [4]. Charcoal contributes to the immobilization of nitrogen [5]. In fact, the addition of charcoal in heavily weakened tropical soils improves their physical, chemical and biological properties [6]. As a result, these soils can acquire good cation exchange capacities (CEC) and better capacities to retain and recycle nutrients over long periods of cultivation [7]. Charcoal also influences the biological community of the soil by its composition and abundance [8]. Indeed, it has a high ratio surface/volume and a high affinity for inorganic ions. Moreover, it has a composition of recalcitrant aromatic compounds which gives it excellent resistance to degradation and a high adsorption power [9]. Generally, activated charcoal is alkaline, but may have a $\mathrm{pH}$ of 4 to 12 depending on the conditions surrounding the manufacturing process [10] [11]. Its use in cropping systems contributes to the reduction of greenhouse gas emissions [12]. The incorporation of activated charcoal on the soil modifies its water state and influences the root development of plants as well as the fauna of the soil [13]. It acts as an adsorbent complex of nutrients, and so helps the soil to fix nutrients like carbon, nitrogen, phosphorus, potassium and calcium [14]. This work is in the context of improving farmers' incomes by reducing the costs of inputs. Its objective is to improve the yield of a local variety of okra, also called "Soudè": Abelmoschus 
caillei. It consisted in evaluating the effect of activated charcoal on the morphological parameters of Abelmoschus caillei. In order to verify the production of all plants, variables were measured on indoor plants and plants from the outside. The variables measured are the mass of the fruits, the height of the plants the numbers of fruits and leaves and the circumferences.

\section{Material and Methods}

\subsection{Material}

\subsubsection{Study Site}

The study was conducted in Zakoua, a village located $5 \mathrm{~km}$ from Daloa (HautSassandra). Zakoua has a tropical climate and records $1317 \mathrm{~mm}$ of rain per year with a temperature ranging from $18^{\circ} \mathrm{C}$ to $32^{\circ} \mathrm{C}$. The geographical coordinates of this locality are: $06^{\circ} 48^{\prime} 06.24^{\prime \prime} \mathrm{N}$ and $06^{\circ} 27^{\prime} 07.58^{\prime \prime} \mathrm{W}$. The study site is located at the edge of a bottom. It is a deep soil with easy access to any season and any means of displacement. The land has a slight slope, is well drained and sandyloamy. The soil moistens rapidly in small amounts of rainfall. However, it wipes away and heats up very quickly. Corn is the previous crop grown on this site bordered by a bottom. The vegetation of Zakoua is currently dominated by fallow.

\subsubsection{Plant Material}

The variety Tomi (Abelmoschus caillei) [1] commonly known as "soundè" was used. The seeds were supplied to us by a peasant from Daloa. In fact, there is considerable popularity among the populations. This vegetable offers better quality and great possibility consumption in dried form.

\subsection{Methods}

\subsubsection{Activation of Charcoal}

Activation of the charcoal consisted of mixing equivalent volumes of coal powder and litter of laying hens. Three coals were activated. For each, 36 buckets of 4 liters of coal were mixed with the same volume of litter of laying hens. These mixtures were spread on surface of $2 \mathrm{~m}^{2}$. They were well moistened and then covered with palm leaves to retain moisture. On each day, the mixtures were stirred, moistened and covered. This operation lasted 30 days. Indeed, activation of the charcoals was carried out progressively as a function of the age of the activated charcoal expected. Thus, activated carbon for 30 days (CA30) was first activated. Then, from the 16th day onwards, activation of the 15-day one (CA15) was triggered. Finally, the CA0 coal was activated on the same day of incorporation of all three charcoal on the ground.

\subsubsection{Preparation of the Ground}

The plot was weeded with a machete and then weeded to the daba. Then it was plowed about $30 \mathrm{~cm}$ deep and crumbled. Finally $2 \mathrm{~m}^{2}$ boards have been made. All these operations are intended to provide a better framework for plant 
development.

\subsubsection{Incorporation of Activated Charcoal on the Ground}

After activation, the activated charcoal was distributed on the boards. To allow a fair distribution a 4 liter bucket was used for distribution. Thus, 4 buckets of activated charcoal were uniformly spread on the surface of each board. Finally, the boards were superficially plowed in order to allow the adhesion of the charcoal.

\subsubsection{Maintenance}

The maintenance of the plot consisted of sanitary control of the plants. Thus, the inter-lines were regularly weeded to keep the farm very clean. This was of interest; the contribution to the best development of plants and the avoidance of certain biological attacks as well as nutritional competitions. Agronomic control has been practiced. It consisted of the uprooting of diseased plants or attacked by diseases. These plants were transferred and then destroyed outside the plot. In addition, the caterpillars and some insects were picked up and thrown out of the plot.

\subsubsection{Data Gathering}

Data were collected on 10 plants selected at random from each plot. They were chosen so that 5 of them were on the edge of the elementary plot and the other 5 were inside the randomized plot.

Fruit harvesting was carried out at physiological maturity. It was done twice a week. The fruits were grouped by plant, by density, by treatment and block at each harvest. The circumference, the number of leaves and the size were recorded on each of these plants. The average mass of the fruits was taken just a few hours after their detachment from the plant. The parameters were measured as follows:

-The average mass $(\mathrm{Ma})$ of fruits per plant was measured on 360 plants

-The distance separating the apex from the stem of each plant and the surface (Tail) of the soil was measured on 360 plants.

-The count of the leaves (NbreFeui) of each plant was carried out on 360 plants.

-Fruit counts (Nbre F) of each plant were carried out on 360 plants

-The size of the main stem of each plant from the section at the insertion of the first leaf (C1) and the last leaf was measured on 360 plants.

\subsubsection{Statistical Analysis of Data}

Three-factor variance analysis (ANOVA 2) was used to evaluate the effect of treatments, and plant position on the plot for each parameter studied.

When a significant difference was observed $(P<0.05)$ between the different factors studied for a given parameter, multiple comparisons were made using the Smallest Significant Difference test. This test made it possible to identify the factor or factors that significantly induce this difference. All statistical tests were performed using the software (SAS, 1999). 


\section{Results and Discussion}

\subsection{Results}

The results of statistical tests evaluating the influence on okra of activated charcoal and plant position in Table 1 showed that the effect of variables such as mass, size, number of fruits, number of leaves, circumference 1 and circum-ference 2 were significantly influenced by activated charcoal and position of plants $(P<0.05) .5$ variables (mass, number of fruits per plant, height of the plant, number of leaves per plant, circumference of the plant measured at the insertion of the first leaf on the plant)out of 6 variables (83\%) were influenced by the type of activated charcoal $(P<0.05) .3$ variables (mass, number of leaves per plant and circumference of the plant measured at the insertion of the first leaf on the plant)out of $6(50 \%)$ influenced by the position of the plants $(P<0.05)$. Double interaction is influenced by mass and number of fruits per plant.

\subsubsection{Influence of Activated Charcoal on Morphological Parameters}

Means of the morphological characters were measured on the activated charcoal and on the absolute control. The influence of the different activated carbons was observed on five (5) of the six (6) characters analyzed. They are the mass, number of fruits, size, number of leaves and circumference 1 . The highest values of mass, size, number of fruits, number of leaves and of the circumference 1 were observed with zero day activated charcoal (CA0). Indeed, CA0 allowed a mass increase of $171.56 \mathrm{~g}$ per plant. The size of each plant was increased by $49.22 \mathrm{~cm}$. The number of fruits and the number of leaves also increased respectively by 5 fruits and 3 leaves. Finally, CA0 increased the circumference 1 by $2.21 \mathrm{~cm}$. These values decrease when the activation time of the coal increases. However, the increase in size (28.72 g), the number of leaves ( 2 leaves) and the circumference 1 $(1.16 \mathrm{~cm})$ per T15 were statistically identical to CA30. Moreover, the circumference 2 of the plants did not differentiate the three activated charcoal and the absolute control $(P>0.05)$. Analysis of the influence of coal on morphological parameters was presented in Table 2.

Table 1. Results of statistical tests evaluating the influence on okra of activated charcoal and plant position.

\begin{tabular}{ccccccc}
\hline \multirow{2}{*}{ Variable } & \multicolumn{2}{c}{ CA } & \multicolumn{2}{c}{ POSI } & \multicolumn{2}{c}{ CA-POSI } \\
\cline { 2 - 7 } & F & P & F & P & F & $P$ \\
\hline Ma & 847.49 & $<0.0001$ & 11.86 & 0.0006 & 17.92 & $<0.0001$ \\
NbreF & 500.56 & $<0.0001$ & 0.03 & 0.8619 & 5.83 & 0.0007 \\
Tail & 114.92 & $<0.0001$ & 0.52 & 0.4698 & 0.02 & 0.9952 \\
NbreFeui & 19.13 & $<0.0001$ & 16.35 & $<0.0001$ & 0.49 & 0.6900 \\
C1 & 54.94 & $<0.0001$ & 9.27 & 0.0025 & 1.36 & 0.2564 \\
C2 & 2.36 & 0.0715 & 2.62 & 0.1061 & 1.89 & 0.1303 \\
\hline
\end{tabular}

Ma: Mass of fruits per plant; NbreF: Number of fruits per plant; Tail: height of the plant; NbreFeui: Number of leaves per plant; C1: Circumference of the plant measured at the insertion of the first leaf on the plant; C2: Circumference of the plant measured at the insertion of the last leaf on the plant; CA: Activated charcoal; POSI (Position): Location of the plants on the elementary plot. 
Table 2. Mean ( \pm standard deviation) of morphological characteristics measured on activated charcoal and statistical test results.

\begin{tabular}{|c|c|c|c|c|c|c|}
\hline \multirow{2}{*}{ Variable } & \multicolumn{4}{|c|}{ Mean ( \pm standard deviation) } & \multicolumn{2}{|c|}{ Statistical } \\
\hline & CAO & CA15 & CA30 & $\mathrm{Te}$ & F & $P$ \\
\hline $\mathrm{Ma}$ & $174.22 \mathrm{~g} \pm 85.57^{\mathrm{a}}$ & $63.70 \mathrm{~g} \pm 17.44^{\mathrm{b}}$ & $49.46 \mathrm{~g} \pm 18.55^{\mathrm{c}}$ & $2.66 \mathrm{~g} \pm 0.53^{\mathrm{d}}$ & 847.49 & $9<0.0001$ \\
\hline NbreF & $6.53 \pm 1.05^{\mathrm{a}}$ & $3.60 \pm 1.16^{\mathrm{b}}$ & $2.73 \pm 0.80^{c}$ & $1.50 \pm 0.75^{\mathrm{d}}$ & 500.56 & $5<0.0001$ \\
\hline Tail & $66.53 \mathrm{~cm} \pm 25.52^{\mathrm{a}}$ & $46.03 \mathrm{~cm} \pm 19.51^{\mathrm{b}}$ & $43.63 \mathrm{~cm} \pm 14.84^{\mathrm{b}}$ & $17.31 \mathrm{~cm} \pm 9.19^{c}$ & ${ }^{c} 114.92$ & $2<0.0001$ \\
\hline NbreFeui & $14.35 \pm 2.74^{\mathrm{a}}$ & $13.15 \pm 2.57^{\mathrm{b}}$ & $13.17 \pm 2.62^{\mathrm{b}}$ & $11.47 \pm 2.79^{c}$ & 19.13 & $<0.0001$ \\
\hline $\mathrm{C} 1$ & $5.94 \mathrm{~cm} \pm 1.43^{\mathrm{a}}$ & $4.89 \mathrm{~cm} \pm 0.95^{\mathrm{b}}$ & $5.178 \mathrm{~cm} \pm 1.52^{\mathrm{b}}$ & $3.73 \mathrm{~cm} \pm 1.05^{\mathrm{c}}$ & c 54.94 & $<0.0001$ \\
\hline $\mathrm{C} 2$ & $2.65 \mathrm{~cm} \pm 0.52^{\mathrm{a}}$ & $2.48 \mathrm{~cm} \pm 0.36^{\mathrm{a}}$ & $2.66 \mathrm{~cm} \pm 0.53^{\mathrm{a}}$ & $2.64 \mathrm{~cm} \pm 0.65^{\mathrm{a}}$ & 2.36 & 0.0715 \\
\hline
\end{tabular}

For each variable, the values with the same letters on the same row are statistically identical. Ma: Mass of fruits per plant; NbreF: Number of fruits per plant; Tail: height of the plant; NbreFeui: Number of leaves per plant; $\mathrm{C}$ : Circumference of the plant measured at the insertion of the first leaf on the plant; C2: Circumference of the plant measured at the insertion of the last leaf on the plant; Te: Absolute witness; CA0: Activated charcoal for 0 days; CA15 charcoal activated for 15 days: CA30 charcoal activated for 30 days.

\subsubsection{Influence of Plant Position on Morphological Parameters}

The statistical analyzes showed that the two positions of the plants influenced the mass, the number of fruits and the circumference 2. In order to evaluate the results according to the position of the plants, the averages were calculated for each position. As a result, the mass $(81.93 \mathrm{~g})$, the number of fruits (14 fruits), and the circumference $2(2.65 \mathrm{~cm})$ were higher outside the elementary plots than in the interior. Indeed, inside, $74.11 \mathrm{~g}$ were obtained at the level of the mass, 12 sheets and $2.56 \mathrm{~cm}$ for the circumference 2. Moreover, no significant difference was observed between the two positions of the plants on the average size, on the number of fruits and on the circumference 2 . The result of the analysis is presented in Table 3.

\subsubsection{Influence of Activated Charcoal-Plant Position Interaction on Morphological Parameters}

Statistical analysis of the variables in Table 4 showed that the mass and number of fruits were influenced by the activated carbon-position interaction. The fruit mass was increased to $191.5 \mathrm{~g}$ with the plants from the outside. However, CA0 was able to increase the mass of the fruits of the plants of the interior only to $156.85 \mathrm{~g}$. However, CA15 increased the mass of fruit from outdoor plants to $58.62 \mathrm{~g}$ and that of indoor plants to $68.77 \mathrm{~g}$. Furthermore, for CA30 and Te, there was no statistical difference in mass between the two positions. At the fruit level, CA0 led to the largest increase, but the two positions gave statistically identical values ( 6 fruits). With CA15, the number of fruits per plant was more statistically increased indoors (3.93 fruits) than externally (3.26 fruits). However, with T15 no statistical difference was observed on the number of fruits between the two positions. Furthermore, the size, number of leaves and circumferences 1 and 2 were not influenced by the activated charcoal-position interaction. 
Table 3. Mean ( \pm standard deviation) of morphological characteristics measured on two positions and statistical test results.

\begin{tabular}{|c|c|c|c|c|}
\hline \multirow{2}{*}{ Variable } & \multicolumn{2}{|c|}{ Mean ( \pm écart-type) } & \multicolumn{2}{|c|}{ Statistical } \\
\hline & Ex & In & F & $\mathbf{P}$ \\
\hline $\mathrm{Ma}$ & $81.93 \mathrm{~g} \pm 81.86^{\mathrm{a}}$ & $74.11 \mathrm{~g} \pm 62.52^{\mathrm{b}}$ & 11.86 & 0.0006 \\
\hline NbreF & $3.58 \pm 2.04^{\mathrm{a}}$ & $3.60 \pm 2.14^{\mathrm{a}}$ & 0.03 & 0.8619 \\
\hline Tail & $44.06 \mathrm{~cm} \pm 24.97^{\mathrm{a}}$ & $42.70 \mathrm{~cm} \pm 25.58^{\mathrm{a}}$ & 0.52 & 0.4698 \\
\hline NbreFeui & $13.58 \pm 2.64^{\mathrm{a}}$ & $12.49 \pm 2.97^{\mathrm{b}}$ & 16.35 & $<0.0001$ \\
\hline $\mathrm{C} 1$ & $5.12 \mathrm{~cm} \pm 1.39^{\mathrm{a}}$ & $4.75 \mathrm{~cm} \pm 1.55^{\mathrm{b}}$ & 9.27 & 0.0025 \\
\hline $\mathrm{C} 2$ & $2.65 \mathrm{~cm} \pm 0.51^{\mathrm{a}}$ & $2.56 \mathrm{~cm} \pm 0.54^{\mathrm{a}}$ & 2.62 & 0.1061 \\
\hline
\end{tabular}

For each variable, the values with the same letters on the line are statistically equal. Ma: Mass of fruits per plant; NbreF: Number of fruits per plant; Tail: height of the plant; NbreFeui: Number of leaves per plant; C1: Circumference of the plant measured at the insertion of the first leaf on the plant; C2: Circumference of the plant measured at the insertion of the last leaf on the plant; Ex: position of the plant at the periphery of the elementary parcel; In: position of the plant inside the elementary plot.

Table 4. Mean ( \pm standard deviation) of the morphological characteristics measured on the interaction between the activation time of the coal and the two positions of the plants and the results of the statistical tests.

\begin{tabular}{|c|c|c|c|c|c|c|c|c|c|c|}
\hline \multirow{3}{*}{ Variable } & \multicolumn{8}{|c|}{ Mean ( \pm écart-type) } & \multirow{2}{*}{\multicolumn{2}{|c|}{ Statistical }} \\
\hline & \multicolumn{2}{|c|}{ CA0 } & \multicolumn{2}{|c|}{ CA15 } & \multicolumn{2}{|c|}{ CA30 } & \multicolumn{2}{|c|}{$\mathrm{Te}$} & & \\
\hline & Ex & In & Ex & In & Ex & In & Ex & In & $\mathrm{F}$ & $\mathrm{P}$ \\
\hline $\mathrm{Ma}(\mathrm{g})$ & $191.59 \pm 97.71^{\mathrm{a}}$ & $156.85 \pm 68.15^{b}$ & $58.62 \pm 11.90^{\mathrm{d}}$ & $68.77 \pm 20.52^{c}$ & $49.49 \pm 21.07^{\mathrm{e}}$ & $49.42 \pm 15.88^{\mathrm{e}}$ & $28.03 \pm 14.99^{\mathrm{f}}$ & $21.39 \pm 9.32^{\mathrm{f}}$ & 17.92 & $<0.0001$ \\
\hline NbreF & $6.60 \pm 1.09^{\mathrm{a}}$ & $6.46 \pm 1.01^{\mathrm{a}}$ & $3.26 \pm 0.71^{\mathrm{c}}$ & $3.93 \pm 1.42^{\mathrm{b}}$ & $2.75 \pm 0.90^{\mathrm{d}}$ & $2.71 \pm 0.69^{\mathrm{d}}$ & $1.71 \pm 0.84^{\mathrm{e}}$ & $1.28 \pm 0.58^{\mathrm{f}}$ & 5.83 & 0.0007 \\
\hline Tail (cm) & $66.91 \pm 26.30^{\mathrm{a}}$ & $66.16 \pm 25.00^{\mathrm{a}}$ & $47.10 \pm 17.09^{\mathrm{a}}$ & $44.96 \pm 21.81^{\mathrm{a}}$ & $44.29 \pm 15.66^{\mathrm{a}}$ & $42.97 \pm 14.12^{\mathrm{a}}$ & $17.94 \pm 8.16^{\mathrm{a}}$ & $16.69 \pm 10.17^{\mathrm{a}}$ & 0.02 & 0.9952 \\
\hline NbreFeui & $14.95 \pm 2.54^{\mathrm{a}}$ & $13.75 \pm 2.83^{\mathrm{a}}$ & $13.82 \pm 2.12^{\mathrm{a}}$ & $12.48 \pm 2.83^{\mathrm{a}}$ & $13.44 \pm 2.71^{\mathrm{a}}$ & $12.91 \pm 2.52^{\mathrm{a}}$ & $12.13 \pm 2.45^{\mathrm{a}}$ & $10.82 \pm 2.97^{\mathrm{a}}$ & 0.49 & 0.6900 \\
\hline $\mathrm{C} 1(\mathrm{~cm})$ & $6.30 \pm 1.52^{\mathrm{a}}$ & $5.59 \pm 1.24^{\mathrm{a}}$ & $5.10 \pm 0.96^{\mathrm{a}}$ & $4.69 \pm 0.90^{\mathrm{a}}$ & $5.18 \pm 0.92^{\mathrm{a}}$ & $5.17 \pm 1.95^{\mathrm{a}}$ & $3.92 \pm 0.95^{\mathrm{a}}$ & $3.54 \pm 1.12^{\mathrm{a}}$ & 1.36 & 0.2564 \\
\hline $\mathrm{C} 2(\mathrm{~cm})$ & $2.65 \pm 0.50^{\mathrm{a}}$ & $2.64 \pm 0.54^{\mathrm{a}}$ & $2.53 \pm 0.35^{\mathrm{a}}$ & $2.44 \pm 0.36^{\mathrm{a}}$ & $2.64 \pm 0.49^{\mathrm{a}}$ & $2.68 \pm 0.58^{\mathrm{a}}$ & $2.78 \pm 0.65^{\mathrm{a}}$ & $2.49 \pm 0.62^{\mathrm{a}}$ & 1.89 & 0.1303 \\
\hline
\end{tabular}

For each variable, the values with the same letters on the line are statistically equal. Ma: Mass of fruits per plant; Number: NbreF of fruits per plant; Tail: height of the plant; NbreFeui: Number of leaves per plant; C1: Circumference of the plant measured at the insertion of the first leaf on the plant; C2: Circumference of the plant measured at the insertion of the last leaf on the plant; CA0: Activated charcoal for 0 days; CA15: activated carbon for 15 days; CA30: coal for 30 days; Te: absolute witness; Ex: position of the plant at the periphery of the elementary parcel; In: position of the plant inside the elementary plot.

\subsection{Discussion}

\subsubsection{Influence of Activated Charcoal on Morphological Parameters}

The respective values of mass, fruit number, leaf number, size and circumference 1 were decreased when the activation time of the charcoal was increased. Thus, a total difference in mass was observed. But, the variation in the number of fruits, leaves number, size and circumference 1 was partial when the activation time of the charcoal was varied. Moreover, the high value of the mass per plant was obtained with CA0. This significant increase in mass could be due to the release of nutrients from the litter and also to the role of charcoal in the soil. Indeed, when the activation time of the charcoal lengthens, the litter releases nutrients. Also, adding water to the coal followed by mixing and covering accelerates decomposition of the litter. This decomposition results in the release of nutrients that can be lost before the supply of charcoal to the soil. And even if these elements are 
not lost before the charcoal is brought to the soil, they would be quickly released before the active need of the plants, which is generally during the filling phase of the fruit at about 60 days from sowing. Therefore, it would not fix cations that are very important to the harmonious functioning of plants, but would promote biological soil activity and improve $\mathrm{pH}$ [14]. The non-retained cations would therefore be exposed to the leaching phenomenon. However, when the mixture is brought to the soil just after its formation (CA0), the charcoal by its negative charge, would fix the anions of the soil and let the cations flocculate. Moreover, the litter would have liberated the elements gradually according to its level of decomposition. Indeed, work carried out on coal by [15] also showed that charcoal immobilizes anions on its surface. These results also corroborate those of [16] which showed that charcoal is a good adsorbent for trace metals.

In general, up to 30 days of activation, coal contributed to the increase in okra yield. Indeed, the mass obtained with CA30 was higher than that given by the absolute control.

\subsubsection{Influence of Plant Position on Morphological Parameters}

An increase in mass was observed with plants from the outside. This increase in the average mass of plants from outside could be explained by a decrease in the competitive effects of plants. Indeed, on the outside the plants flourished and spread better, enjoy the best conditions (sunshine, hygrometry less attacks). This allows them a good assimilation of the nutrients thus contributing to a better synthesis of carbonaceous substances accumulated in the fruits [17].

\subsubsection{Influence of Activated Carbon-Plant Interaction on Morphological Parameters}

The average mass and the number of fruits per plant are influenced by the treatment-position interaction. An inverse correlation was observed under this interaction. These values have been decreased with increasing the activation time of the charcoal and with the plants of the interior. This could be explained by the fact that $\mathrm{CO}_{2}$ efficiently provides the nutrients that are better assimilated by plants from outside with little or no competition [18].

\section{Conclusion and Perspectives}

The use of activated charcoal associated with the position of plants in this work, is very beneficial for the cultivation of okra in the sandy loam soil. Therefore, zero-day activated charcoal is beneficial for the cultivation of okra on the sandy loam soil. Indeed, although charcoal has had several advantages to its potential as a soil amendment, its properties may vary depending on the type of soil, depending on the growing conditions. For the time being, it would be difficult to standardize the effects of activated charcoal on okra from a single study. However, economically and from an environmental point of view, activated charcoal appears to be a good substitute for chemical inputs. However, it is necessary to be able to characterize activated charcoal well and to use it in cropping systems. 
The results of this study therefore offer an alternative to okra producers in order to comply with environmental standards. They will therefore be able to limit the leaching of certain elements such as phosphorus and nitrates without however having a negative impact on the productivity of the crops. This study thus presents a means of limiting the intake of fertilizers while meeting the needs of the plant. In addition, the charcoal associated with the position of the plants has allowed better availability and a good use of the nutrients by the crop.

In addition, soil analysis before and after okra cultivation would be necessary. Also, biochemical analysis would be useful to qualify the nutritional value of okra. It would still be necessary to carry out this experiment on different types of soil and at different seasons to standardize the effect of activated charcoal.

\section{Acknowledgements}

Our thanks go to the authorities of the Jean Lorougnon GUEDE University in Daloa (Côte d'Ivoire) and the research group of plant physiology of this University for their contribution to the realization of this work.

\section{References}

[1] Fondio, L., Christophe, K., André, D. and Traoré, D. (2011) Caractérisation des systèmes de culture intégrant le Gombo dans le maraichage urbain et périurbain de Bouké dans le centre de la Côte d'Ivoire. International Journal of Biological and Chemical Sciences, 5, 1178-1189. http://ajol.info/index.php/ijbcs

[2] Anonymous (2009) (FAO) Rapport national sur l'état des ressources phytogénétiques pour l'alimentation et l'agriculture. $11 \mathrm{p}$.

[3] Yao, Y., Gao, B., Zhang, M., Inyang, M. and Zimmerman, A. (2012) Effect of Biochar Amendment on Sorption and Leaching of Nitrate, Ammonium, and Phosphate in a Sandy Soil. Chemosphere, 89, 1467-1471. https://doi.org/10.1016/j.chemosphere.2012.06.002

[4] Warnock, D.D., Lehmann, J., Kuyper, T.W. and Rillig, M.C. (2007) Mycorrhizal Responses to Biochar in Soil-Concepts and Mechanisms. Plant and Soil, 300, 9-20. https://doi.org/10.1007/s11104-007-9391-5

[5] Lehmann, J., Gaunt, J. and Rondon, M. (2006) Bio-Char Sequestration in Terrestrial Ecosystems-A Review. Mitigation and Adaptation Strategies for Global Change, 11, 395-419. https://doi.org/10.1007/s11027-005-9006-5

[6] Glaser, B., Lehmann, J. and Zech, W. (2002) Ameliorating Physical and Chemical Properties of Highly Weathered Soils in the Tropics with Charcoal: A Review. Biology and Fertility of Soils, 35, 219-230. https://doi.org/10.1007/s00374-002-0466-4

[7] Laird, D., Fleming, P., Wang, B., Horton, R. and Karlen, D. (2010) Biochar Impact on Nutrient Leaching from a Midwestern Agricultural Soil. Geoderma, 158, 436442. https://doi.org/10.1016/j.geoderma.2010.05.012

[8] Liang, B., Lehmann, J., Sohi, T.J., O’Neill, B., Trujillo, L., Gaunt, J., Solomon, D., Grossman, J., Neves, E. and Luizão, F. (2010) Black Carbon Affects the Cycling of Non-Black Carbon in Soil. Organic Geochemistry, 41, 206-213. https://doi.org/10.1016/j.orggeochem.2009.09.007

[9] Lehmann, J. and Joseph (2009) Biochar for Environmental Management: Science and Technology. Earthscan, London, 405 p. 
[10] Lehmann, J. (2007) Bio-Energy in the Black. Frontiers in Ecology and the Environment, 5, 381-387.

[11] Cheng, C.-H., Lehmann, J., Thies, J.E., Burton, S.D. and Engelhard, M.H. (2006) Oxidation of Black Carbon by Biotic and Abiotic Processes. Organic Geochemistry, 37, 1477-1488. https://doi.org/10.1016/j.orggeochem.2006.06.022

[12] Gaunt, J.L. and Lehmann, J. (2008) Energy Balance and Emissions Associated with Biochar Sequestration and Pyrolysis Bioenergy Production. Environmental Science \& Technology, 42, 4152-4158. https://doi.org/10.1021/es071361i

[13] Major, J., Steiner, C., Downie, A. and Lehmann, J. (2009) Biochar Effects on Nutrient Leaching. Soil Fertility Management et soil Biogeochemistry, 32 p.

[14] Sohi, S. (2012) Carbon Storage with Benefits. Science, 338, 1034-1035. https://doi.org/10.1126/science.1225987

[15] Sara, L. (2015) Effet de l'amendement en biochar des sols biologiques pour une culture de tomate sous serre: Rétention des nutriments, activités biologiques, et régie de fertilisation. Advances in Agronomy, 5, 9-14.

[16] Zue, M. (2012) Élimination des ions Mn (II) des solutions aqueuses par adsorption sur des charbons actifs préparés à partir des coques de noix de noisette. Mémoire pour l'obtention du diplôme de Master ès Sciences Spécialité Chimie Option: Chimie des Matériaux, Université des Sciences et Techniques de Masuku (Gabon); $74 \mathrm{p}$.

[17] Dje, B., Kouamé, K., Baudoin, J. and Zoro, B. (2011) Effets de la saison de culture et de la densité des plants sur les adventices et la production de la cucurbite oléagineuse citrulluslanatus (thunberg). Sciences \& Nature, 8, 85-93. https://www.ajol.info/index.php/scinat

[18] Charles, H. and François, L. (2012) Le point sur les expérimentations menées à la ferme du Bec. Hellouin, 6 p.

\section{Scientific Research Publishing}

\section{Submit or recommend next manuscript to SCIRP and we will provide best service for you:}

Accepting pre-submission inquiries through Email, Facebook, LinkedIn, Twitter, etc. A wide selection of journals (inclusive of 9 subjects, more than 200 journals)

Providing 24-hour high-quality service

User-friendly online submission system

Fair and swift peer-review system

Efficient typesetting and proofreading procedure

Display of the result of downloads and visits, as well as the number of cited articles

Maximum dissemination of your research work

Submit your manuscript at: http://papersubmission.scirp.org/

Or contact ajps@scirp.org 